\title{
Beyond Surrealism: Georges Limbour
}

\section{Donald Heiney}

It is curious that the formal Surrealist movement produced almost no fiction of any importance. Partly this was because of the quite personal animadversion of Breton for the novel as a form, for "all that partakes of anecdote." Like Valéry he refused to write that the Marquise went out at five o'clock. The trouble with novelists, he offered in the first Manifesto, was "the circumstantial and uselessly particular character of their profusion of references, which leads me to think they are amusing themselves at my expense." The documentary, that is the mimetic, was rejected in favor of the oneiric. Yet for whatever reason his own Nadja, like Aragon's Le Paysan de Paris, was unable to break through reportage and mémoir to the creation of a genuinely imaginative narrative, one that would relate not only "what happened," either outside or inside the author's head, but what might be, and what existed only after its construction by the creative imagination. This achievement was left to a later wave of writers only peripherally connected to the Surrealist movement or not connected to it at all: Borges, Calvino, Cortázar, Limbour, and Julien Gracq. The peculiarity of this tendency (it is not a school, and its members are hardly in communication with one another at all) is that the realistic revolution in technique is not repudiated, but neither does the writer limit himself to description of the real world. Instead the documentary method is used as a base for extrapolation into the fantastic and artificial, for the creation of synthetic worlds which may then be inhabited, like the worlds of Magritte and Paul Delvaux. This might in the true sense of the word be termed a "fiction," and in fact Borges calls his tales Ficciones.

Limbour was born in Courbevoie in 1900 and was thus only a little younger than the main body of Surrealists. His early association with the movement was due more to a misunderstanding than anything else. He is mentioned three times in the first Manifesto (1924), and his poems of this period somewhat resemble those of Apollinaire. The difference of opinion was over whether one ought to write for a readership, however small, and in general over the question of communicability and coherence. A split also developed between the political activists and the advocates of art-for-art. By 1929 the movement had become increasingly politicized, and increasingly under the domination of Breton's ego. Limbour stood accused of "complacence toward literature," and Breton definitely threw him overboard in the second Manifesto, along with Artaud, Soupault, Vitrac, and the painter André Masson. Limbour later wrote two books on Masson, one in collaboration with Michel Leiris. The interest in Masson's "anecdotal" but fractured and pyrotechnic canvases coincides with Limbour's own definite abandonment of poetry in favor of fiction.

The four novels and numerous stories and sketches he produced between 1930 and 1963 are, in some respects, an extension of his Apollinairesque poetry. It is an odd fiction, rich in energy and full of partly resolved conflicts. There is a great 
note of enthusiasm and sensual delight running through it, yet the verbal effervescence is always tempered by intelligence. Leiris characterizes him as a being "intoxicated with life and at the same time too lucid not to perceive its inanity." The heroic is established in deft sketches and then deflated by the playful. In an early poem the blunderbusses of Calabrian bandits in old prints are assimilated to clarinets: "They only raise their guns to waft a love-song in your ear." Most of the settings are exotic: Réunion in Les Vanilliers, a Danubian city in Le Bridge de Madame Lyane, Spain in La Pie voleuse and La Chasse au mérou. Ignoring the adventures of two world wars and the dramas of domesticity, he writes about his vacations. For Limbour this is not escapism but only aesthetic preference; "escape" lies in the direction of household and bourgeois employment, the sand and warm summer sea represent keenness and excitement. Yet the vacationer is never a full participant in what he sees, always partly a spectator. This is one of the unresolved tensions.

Fitting our definition, this "fiction" is built on a base of documentary realism but extends beyond it into purely synthetic frameworks of experience. The model of this technique is The Metamorphosis, which is not verbally spectacular at all but related in the style of the meticulous insurance adjuster who wrote it. Gregor Samsa's little legs wiggling in the air, his efforts to turn himself over, give the impression not so much of hallucination as of an industrial accident. If Limbour never achieves this purity it is because he has difficulty freeing himself from the verbal ingenuities, the desire to surprise, of his early surrealist manner. But his epistemology is fundamentally a Kafkaesque one. It is the opposite of the "knowing" style that dominates much of modern fiction, full of reference to a large body of sophistication shared by the author and his reader. On the contrary, in Limbour as in Kafka, there is a deliberately imposed naïveté, a freshness of view which is nevertheless arrived at from a position of great intellectual complexity: the glance not of the newborn infant but of Lazarus. We owe to the Russian formalists a convenient term for this: "making it strange." Shklovsky applies it to Tolstoy. An opera is described as though seen by a highly intelligent but deaf Martian; the copious and "unnecessary" triviality of a battle scene is reported by a camera. The familiar texture of experience is rejuvenated by being shown as though it had never happened before. A bowling alley in La Chasse au mérou is seen exactly with this Martian eye.

. . . I found myself before a long lane of beaten red earth, poorly lighted except at the end where a skinny coppery old man, down from the mines in the mountains, set upright the knocked-down pins. His rôle was also to send the balls back to the players by rolling them on a wooden rail that descended and then went up again in curves like a scenic railway, so that the heavy balls lined up in horizontal rank all by themselves, like the beads of a giant necklace.

An Updike or Herbert Gold would have given us a copious measure of the terminology of bowling and even its slang, as Gold does for carnivals in The Man Who Was Not With It. This is what they know, or more precisely what their books know. The author and his somewhat jaded and oversophisticated reader 
share all the facts, and a large part of the pleasure of reading lies in the common knowingness. What Limbour knows is only what his Lazarus-eye sees. Thus a sentry in Le Bridge de Madame Lyane:

He was immobile now, rifle on his shoulder and totally rigid. Very slowly and without bending his knee he projected a foot forward, then abruptly flung it with all his might onto the pavement as though he were stamping on an enormous beetle, but without anger. Then, stiffly, his loins arched and his glance fixed, he took several seconds, without losing balance, to bring up to the position of the down-smashing foot the other foot whose point vertically grazed the ground.

It would be tempting to call this freshness Homeric except that Homer has no sense of the ridiculousness of what most of us do all day long. Certainly it is not heroic; the vein of irony makes that impossible. Even when the metaphor follows the epic pattern, juxtaposing the wonderful and the familiar, the effect is playful. A midnight sky in "Le Chien blanc" becomes "a field of camomile with sleep descending from it." For Nerval or Henri Michaux the descending soporific would have been opium; the camomile is the reductive pin-prick, the touch of the mind "too lucid not to perceive the inanity" of the perception.

Through the technique of Making It Strange the line between the organic and material is blurred; the human becomes mechanical and machinery is animized. La Chasse au mérou is full of automobiles, diving equipment, and apparatuses for evaporating salt, and these contrivances all manage to assume a life of their own or are made metaphors in some way like the blunderbusses. The tram in Le Bridge de Madame Lyane, full of lights and clicking, is operated by a "wattman" who stands on a platform like that in Hamlet and makes it go by "circular motions of his hand," but this magician seems only partly in charge of his vehicle, which emits sparks from its own quite private personality somewhere underneath. The epitome of these contrivances is the funicular in the same novel, which combines the electricity of the tram with the lightness of the balloon. It is the non-Euclidean vehicle par excellence. It has a queer shape, non-rectangular and half-crushed, like "one of those ridiculous animals that nature out of whim has decided to make unlike the others." It looks as though a giant has stepped on it. From it the passenger, as from all elevated railways and suchlike, can see into privacies ordinarily hidden from view, hospital rooms where white-clad nurses with white trays serve white-faced patients. Such scenes are ordinarily revealed only to the imagination of the novelist. Fiction, for Limbour, is a kind of celestial tramway that moves by sparks and offers strange views, rendering ordinary things fantastic through the angle of vision.

The narrative syntax is discontinuous, as fractured as the anecdotes of Masson's canvases. The metaphor is everywhere. He is dominated a little too much, perhaps, by the demon of analogy. A watering truck in Le Bridge de Madame Lyane sprouts a fan at the rear "like a gypsy's mustache"; in La Chasse au mérou the sail of a becalmed boat is "wrinkled like the skin of a dead eye, as empty as a dried breast." In Les Vanilliers a ship comes to anchor, its sails dropping one by one like the petals of a flower, "as though the wind of the island was poisoned." 
Grief and ecstasy, all the passions, are treated as mechanisms and yet remain oddly moving. A girl in the same novel: "The tears had left on her face the silver and shining traces drawn on large leaves by small white snails. She would never have more beautiful or more touching jewels ..." The verb and noun can no longer contain the richness and it spills over-flouting all rules of freshman composition-into the adjective and adverb. But the style is less sentimental than it seems at first. In spite of the curlicues and little flourishes it is tightly controlled; the excesses are not really effusive or emotional, they are gongoristic. A verve of irony chills them sufficiently to avoid the mawkish. As in the painting of Delvaux or Magritte, the basic unit-block of the work (the phrase, the line) is craftsmanlike and therefore lucid and precise. The adjective-laden style is still somewhat indigestible for the Anglo-Saxon mind, especially in translation. In American literature attempts at such effects are usually failures.

It [a train] halted only long enough to disgorge the two dogs: a thousand costly tons of intricate and curious metal glaring and crashing up and into an almost shocking silence filled with the puny sounds of men, to vomit two gaunt and cringing phantoms whose droopeared and mild faces gazed with sad abjectness about the weary, pale faces of men who had not slept very much since night before last, ringing them about with something terrible and eager and impotent.

Something is wrong with this. What a lot of fuss about two dogs that will not be able to find Miss Burden's murderer anyhow! The effort to wring emotion from relatively prosaic facts through linguistic ornament is foreign to the idiom and its whole tradition, from Mark Twain on. Faulkner is "a great talker," too much so in fact to be trusted. The train glares and crashes, but it does not see into hidden places. Limbour's funicular, his ship dropping its petals, are far more fragile and polite, they are that funny poetry they tried to make us learn in school, but the girl's snail-tears touch more than the sad faces of the hounds.

Limbour's fiction is rich in incident but not in plot. What happens seems mysteriously important, but in ways we cannot quite make out, just as in a good deal of life itself. "Le Chien blanc" has the same lucid ambiguity as "Stopping by Woods on a Snowy Evening," produced with virtually the identical elementsan animal, snow, cold, darkness, a spectator who is contemplative and at the same time personally involved. In the novels this gnomic quality is multiplied into more complex textures. La Pie voleuse rather kaleidoscopically deals with the life of a Spanish village before and after the Civil War; as in "Guernica" we get an affective picture of the horrors without quite being able to delineate one figure from another. The odd bar and bridge club presided over by Madame Lyane is seen through an equally distorted optic but a different one, more like Chagall or Soutine than Picasso. The figures elongate, stretch, distort, but are not quite able to embrace. Les Vanilliers concerns vanilla-growing on an island in the Indian Ocean. The flower of this plant contains both male and female parts, separated by a membrane that must be pierced by some small sharp object-for example, the tooth of a girl's comb-for their fecundation. Nature itself imitates the preciosity of Limbour's world in which everything is complicated and yet at 
the same time simple, the incompatibles reconciled by a playful symbolism. The dénouement, as it happens, is mock-tragic; a shipload of hummingbirds is brought from Mexico to devirginize the flowers, but the cargo dies en route and the only birds that arrive are a few that have been stuffed by the sailors.

The last and probably the best of the novels, La Chasse au mérou, is the most conventional in structure, held together by its basically picaresque outline. Enrico, a student of the University of Salamanca, hitchhikes his way to a fishing town near Cartagena for a vacation of sea and sunshine. He brings his diving gear because he hopes to catch the great grouper whose presence is fabled in those waters. On the way he tears from his knapsack the small embroidered triangle that proclaims his membership in the university; like Limbour he is an academic who prefers to shed his erudition in the summer. The incidents are linked together in a half-serious and oblique symbolism that finally joins on itself and is complete: Nise the mysterious bar-girl, the bowling alley in the Cartagenian garden, the camaraderie with the other young divers in the fishing village, the mock-Melvillian chase for the grouper who lurks under a ledge in deep water. The boiling of the great fish when captured, in a washtub, is another fine piece of Making It Strange. In the garden of a seaside café the Spanish students and vagabondschaste and amorous, grave in their Iberian way-make a great feast.

It's now that the Grouper Hunt begins! Drink to the death of the fatassed sattrap, the callipygian tyrant. He'll get his spearpoint. We'll see his naked bones twisting in the sun like these fishbones. And we'll bury him without song and without music.

This is all the politics to be found in Limbour, a lifelong lover of Spain for whom there are no abstracts and people are quite simply their surfaces. Always he is wary of the emphatic, the absolute. He only plays with the Homeric and offers us the Melvillian with a little smile; he believes in living only fairly dangerously. His death in 1970 was accidental.

\section{Selected Bibliography Georges Limbour}

Soleils bas (poems). Paris, Galerie Simon, 1924.

L'Illustre Cheval blanc (tales). Paris, Gallimard, 1930.

Les Vanilliers (novel). Paris, Gallimard, 1938.

La Pie voleuse (novel). Paris, Gallimard, 1939.

L'Enfant polaire (tale). Paris, Fontaine, 1945.

Le Bridge de Madame Lyane (novel). Paris, Gallimard, 1948.

La Chasse au mérou (novel). Paris, Gallimard, 1963.

Soleils bas (enlarged edition; poems and fiction). Paris, Gallimard, 1972.

Contes et récits (includes two stories from L'Illustre Cheval blanc). Paris, Gallimard, 1973. 